Review

\title{
Exercise Benefits Brain Function: The Monoamine Connection
}

\section{Tzu-Wei Lin ${ }^{1}$ and Yu-Min Kuo ${ }^{1,2, *}$}

1 Institute of Basic Medical Sciences, National Cheng Kung University, Tainan 70101, Taiwan; E-Mail: s58991219@mail.ncku.edu.tw

2 Department of Cell Biology and Anatomy, National Cheng Kung University, Tainan 70101, Taiwan

* Author to whom correspondence should be addressed; E-Mail: kuoym@mail.ncku.edu.tw; Tel.: +886-6235-3535 (ext. 5294); Fax: +886-6209-3007.

Received: 13 September 2012; in revised form: 29 October 2012 / Accepted: 7 January 2013 / Published: 11 January 2013

\begin{abstract}
The beneficial effects of exercise on brain function have been demonstrated in animal models and in a growing number of clinical studies on humans. There are multiple mechanisms that account for the brain-enhancing effects of exercise, including neuroinflammation, vascularization, antioxidation, energy adaptation, and regulations on neurotrophic factors and neurotransmitters. Dopamine (DA), noradrenaline (NE), and serotonin (5-HT) are the three major monoamine neurotransmitters that are known to be modulated by exercise. This review focuses on how these three neurotransmitters contribute to exercise affecting brain function and how it can work against neurological disorders.
\end{abstract}

Keywords: exercise; brain function; monoamine

\section{Introduction}

Regular physical exercise has been proved to have therapeutic benefit [1], such as treating psychiatric illnesses [2-7], supporting brain injury recovery [8-12], and resisting neurodegenerative diseases [13-18]. The advantageous effects of exercise on brain functions have been attributed to increased capacities of metabolism reserve and antioxidation [19,20]. Furthermore, regulations of the secretion of neurotrophic factors, vasculotropic factors, inflammatory mediators, and neurotransmitters are also involved in exercise's influence on brain function [21-25]. Among these effects, secretion of neurotransmitters, especially monoamines, have been linked to the exercise-induced neuronal adaptation. Interplay between exercise and monoamines was initially derived from the "Central Fatigue 
Hypothesis", in which increased brain 5-HT release was found to be associated with central fatigue [26,27]. 5-HT is linked to fatigue because of its known effects on sleep, lethargy, and loss of motivation. The hypothesis prompted researchers to investigate the role of 5-HT in exercise-induced central fatigue [28-33]. Results suggest that exercise-induced central fatigue is more complex and depends on the intensity and duration of exercise. Overtraining exercise may stimulate hyperactivation of the monoamine systems which could cause fatigue [34-36]. Rodents that receive exhaustive treadmill exercise have higher 5-HT in the midbrain, striatum, hypothalamus and hippocampus [37]. The levels of dopamine are increased only in the striatum, although the levels of DOPAC, the major DA metabolite, are increased in both midbrain and striatum. On the other hand, exhaustive treadmill exercise reduces NE levels in the hypothalamus and brain stem [38]. Chronic moderate exercise is also known to stimulate the monoamine systems, but exercise of this sort does not induce central fatigue. Instead, chronic moderate exercise has been recognized as one of the most effective ways to enhance the adaptation/plasticity of the central nervous system (CNS). In addition, clinical studies suggest that monoamine systems play central roles resistance and recovery induced by chronic moderate exercise from various diseases like mental disorders [39] and Parkinson's disease (PD) [40]. This article reviews recent studies that emphasize the effects of exercise on brain functions due to monoamine systems.

\section{Physiological Properties of DA, NE and 5-HT}

The catecholamines (DA, NE) and 5-hydroxytryptamine (5-HT) are the chief players of the monoamine neurotransmitter family. All three monoamines can be re-uptake by specific transporters from the synaptic spaces back into cytosol. Furthermore, they share common activation mechanism mediated through $\mathrm{G}$ protein-coupled receptors (GPCRs). We shall first briefly introduce the biosynthesis of DA, NE and 5-HT, as well as the biological properties of their receptors.

\subsection{Dopamine (DA) System}

DA is synthesized from L-dihydroxyphenylalanine (L-DOPA), which is catalyzed from amino acid tyrosine by enzyme tyrosine hydroxylase. L-DOPA is then converted to DA by the catalysis of enzyme DOPA decarboxylase (or aromatic amino acid decarboxylase). In the CNS, dopaminergic neurons mainly reside in two nuclei of the midbrain: substantia nigra and ventral tegmental nucleus. Axons of the dopaminergic neurons in the substantia nigra project to the striatum (nigrostriatal pathway) which in turn is responsible for movement behavior. Axons of the ventral tegmental nucleus dopaminergic neurons project to the entire cortex (mesocortical pathway) and nucleus accumbens (mesolimbic pathway), which are involved in cognition and reward responses, respectively.

There are five types of DA receptors (D1 to D5), which are simply categorized in two families of GPCR: D1-like and D2-like receptors. The D1-like receptor family contains D1 and D5 receptors that are coupled with $\mathrm{G}_{\mathrm{s}}$ and $\mathrm{G}_{\mathrm{q}}$ protein [41-44]. The D2-like receptor family comprises of D2, D3 and D4 receptors which couple with the $G_{i}$ proteins to inhibit adenylyl cyclase [43,44]. D2-like receptors can be found on both pre- and post-synaptic terminals, while D1-like receptors are mainly located at post-synaptic sites [43]. The actions of DA receptors on membrane excitability are well defined in the striatal neurons [45-49]. Both D1 and D2 receptors are capable of modulating long-term depression; activation of D1 receptor enhances long-term depression, while activation of D2 receptor inhibits 
long-term depression [50]. Furthermore, D1 and D2 receptors modulate motor functions by modifying the excitatory transmission between the presynaptic cortical glutamatergic neurons and the post-synaptic striatal GABAergic neurons [46].

\subsection{Norepinephrine (NE) System}

NE is synthesized by further hydroxylation of DA. In the CNS, NE is released by the noradrenergic neurons which are mainly present in the locus coeruleus. The axons of noradrenergic neurons innervate the whole cerebral cortex, various subcortical areas, cerebellum and brain stem [51].

Traditionally, noradrenergic receptors are divided into three types: $\alpha_{1}, \alpha_{2}$ and $\beta$. So far, three $\alpha_{1}$ subtypes $\left(\alpha_{1 \mathrm{a}}, \alpha_{1 \mathrm{~b}}, \alpha_{1 \mathrm{~d}}\right)$, four $\alpha_{2}$-receptor subtypes $\left(\alpha_{2 \mathrm{~A}-\mathrm{D}}\right)$, and three $\beta$ subtypes $\left(\beta_{1-3}\right)$ receptors have been identified; all of them are the members of the GPCR [52]. The $\alpha_{1}$ and $\beta$ receptors are present primarily at the postsynaptic sites, whereas $\alpha_{2}$-receptors exist at both pre- and postsynaptic terminals. $\alpha_{1}$ receptor is the most abundant adrenergic receptor in the brain [53]. Binding of NE to $\alpha_{1}$ receptor, a $\mathrm{G}_{\mathrm{q}}$ coupled receptor, activates phospholipase $\mathrm{C}$, which in turn produces inositol 1,4,5-trisphosphate and diacylglycerol to regulate intracellular $\mathrm{Ca}^{2+}$ concentration and the activation of PKC. $\alpha_{2}$ Receptor, a $G_{i}$ coupled receptor, whose main function is to increase glycogenesis in neurons [54]. $\beta$ Receptor, linked to $G_{s}$ protein, can either activate PKA through activating adenylyl cyclase and cAMP or cause apoptosis via the Src family tyrosine kinase-dependent pathway [55]. The activity of these receptors carries out a variety of tasks in the CNS.

\subsection{Serotonin (5-HT) System}

5-HT is synthesized from L-tryptophan, which is first catalyzed by tryptophan-5 hydroxylase to form 5-hydroxytryptophan and then further converted to 5-HT by aromatic L-amino acid decarboxylase. The axons of serotonergic neurons, primarily from the median and dorsal raphe nuclei, project to the entire CNS. 5-HT is regarded as the keystone in the psycho-emotional symptoms of depression and anxiety [56,57]; antagonists of 5-HT transporter have been widely used to ameliorate neuropsychiatric symptoms [58].

Seven classes of $5-\mathrm{HT}$ receptors $\left(5-\mathrm{HT}_{1}\right.$ to $\left.5-\mathrm{HT}_{7}\right)$ have been identified. Except for the $5-\mathrm{HT}_{3}$ receptor, which is a ligand-gated ion channel, all the other 5-HT receptors belong to GPCR family [59]. Previous efforts in clarifying the effect of exercise on brain function focus primarily on $5-\mathrm{HT}_{1 \mathrm{~A}}, 5-\mathrm{HT}_{1 \mathrm{~B}}$ and $5-\mathrm{HT}_{2 \mathrm{~A}}$ receptors. Alterations of 5- $\mathrm{HT}_{1 \mathrm{~A}}, 5-\mathrm{HT}_{1 \mathrm{~B}}$ and $5-\mathrm{HT}_{2 \mathrm{~A}}$ levels have been linked to the development of anxiety, depression and psychiatric disorders such as schizophrenia [60-70], making these three types of receptor favorable targets for drug treatment. All six subtypes of 5- $\mathrm{HT}_{1}$ receptor $\left(5-\mathrm{HT}_{1 \mathrm{~A}-\mathrm{F}}\right)$ are members of the $\mathrm{G}_{\mathrm{i}}$-coupled receptor family and function to inhibit adenylyl cyclase activity. 5- $\mathrm{HT}_{1 \mathrm{~A}}$ receptors are highly expressed not only at the somatodendritic sites (autoreceptor) of raphe nuclei, but also at the postsynaptic sites of limbic area, especially the hippocampus [59]. 5- $\mathrm{HT}_{1 \mathrm{~B}}$ receptors function as the terminal autoreceptor and are enriched in the basal ganglia, striatum and frontal cortex. In addition, 5- $\mathrm{HT}_{1 \mathrm{~B}}$ receptors may also behave as a terminal heteroreceptor to control the releases of acetylcholine, glutamate, DA, NE and GABA [59,71]. The 5- $\mathrm{HT}_{2}$ class consists of the 5- $\mathrm{HT}_{2 \mathrm{~A}}, 5-\mathrm{HT}_{2 \mathrm{~B}}$ and $5-\mathrm{HT}_{2 \mathrm{C}}$ receptors. 5- $\mathrm{HT}_{2 \mathrm{~A}}$ 
receptors are mainly located in the cortex, claustrum and basal ganglia. Activation of 5- $\mathrm{HT}_{2 \mathrm{~A}}$ receptors results in neuronal depolarization via the phospholipase $\mathrm{C}-\mathrm{Ca}^{2+} / \mathrm{PKC}$ pathway [72].

\section{Exercise Modulates the Activities of DA, NE and 5-HT Systems}

A plethora of evidence from animal and human studies indicates that physical exercise improves health, both physically and mentally [73-75]. In the follow section, we will discuss how exercise, via the regulations of monoamine systems, enhances physical and mental adaptive capacities in order to cope with external/internal challenges and maintain homeostasis.

\subsection{Exercise and DA System}

Exercise is known to change the DA system in the CNS. Using a radioenzymatic assay followed by a thin-layer chromatography, the concentrations of DA are found to be upregulated in brain homogenates of rats subjected to eight weeks of food-reinforced running-wheel exercise, while a compensatory down-regulation of DA receptor densities is evident in these animals [76]. Upregulation of DA in the brain has been linked to exercise-induced higher levels of serum calcium, which is transported into the brain and affects calcium/calmodulin-dependent DA synthesis by activating the tyrosine hydroxylase enzyme [77]. Furthermore, the binding affinity between DA and DA receptor, determined by $[3 \mathrm{H}]$ spiroperidol binding, is also increased by exercise training $[78,79]$.

Interestingly, cerebral infarction induced by photothrombosis increases striatal DA content levels [80]. The infarction-induced increases of striatal DA level are reduced by eight days of running-wheel exercise initiated from two days after infarction. Furthermore, running-wheel exercise-induced increases of cortical levels of DA cannot be reproduced in the female R6/1 mice, a model of Huntington disease [81]. In a MPTP-induced PD animal model, treadmill exercise not only increases the stimulus-evoked DA release but also decreases the decay of DA in the dorsal striatum as determined by fast-scan cyclic voltammetry technique [82]. It has been shown that treadmill exercise counteracts the MPTP-induced motor dysfunction by increasing the levels of DA-D2R mRNA and decreasing the levels of striatal DA transporter protein [83]. More recently, upregulation of striatal dopamine D2 receptor by treadmill exercise in the MPTP-induced PD mouse model has been validated by positron emission tomography [84]. The beneficial effects of exercise, both wheel and treadmill running, can be confirmed in a different PD animal model -6-hydroxydopamine-induced dopaminergic neuron death [85-87]. In addition to the therapeutic effects, exercise also provides protection against neurotoxicity. Three months of wheel exercise prior to MPTP treatment protects dopaminergic neuron against MPTP-induced loss in the substantia nigra of mice [88]. Furthermore, in peripheral inflammation-induced PD animal model, four weeks of treadmill exercise before inflammation has been shown to prevent the inflammation-induced dopaminergic neuron loss [89].

Studies of patients with PD suggest that exercise may provide preventive and non-pharmaceutical therapeutic approach for PD. Six months of aerobics exercise significantly improves the executive movement of simple and complex motions in patients diagnosed with mild to moderate PD [90]. Additionally, in an epidemiological evaluation of physical activity in a cohort of more than 200,000 participants, exercise at moderate to vigorous levels is found to protect against PD [91]. Altogether, 
exercise not only modulates the direct action of DA system, but also protects DA neuron against toxic assaults.

\subsection{Exercise and NE System}

In response to external stimuli and the pressure of survival, animals adapt themselves physically and mentally. Exercise is known to enhance neuronal adaptation against harmful stimuli associated with stress. When subjected to inescapable tail shock, an elevation of c-Fos protein, an indication of neuronal activity, occurs in neurons of locus coeruleus [92]. Such stress-induced neuronal activation in the locus coeruleus is reduced by six weeks of wheel running, suggesting that exercise provokes neuronal adaptation in response to uncontrollable stress [92,93]. The protective mechanism of exercise against stress has been attributed to the expression of galanin in locus coeruleus [94]. Galanin hyperpolarizes noradrenergic neurons and inhibits locus coeruleus neuronal firing, leading to a suppression of NE release [95,96]. Reduced NE release from locus coeruleus to target areas, such as frontal cortex and amygdala, confines anxiety behavior [94]. Both chronic treadmill and running-wheel exercise increase the expression of galanin gene in the locus coeruleus [97-100]. Furthermore, the levels of plasma galanin are also increased in humans after acute exercise [101].

In addition to stress resistance, NE also participates in commanding the consolidation and retrieval of memory [102,103], especially emotional memory [104]. Loss of noradrenergic neurons in locus coeruleus has been implied to be involved in the symptoms of cognitive impairment in PD and Alzheimer's disease $[105,106]$. Both chronic treadmill and wheel exercise increase the levels of NE in the pons-medulla and spinal cord as compared to sedentary controls [107]. Similarly, the levels of NE in brain regions that are linked to cognitive function, including hippocampus and central and medial amygdala, are elevated by chronic treadmill exercise [108]. Blockade of $\beta$-adrenoreceptors with various antagonists inhibits the chronic exercise-induced improvement of learning and memory in contextual fear conditioning and water maze tasks [100,109]. The memory performance in both amnestic mild cognitive impairment patients and control subjects is significantly enhanced if a single bout of aerobic exercise is given immediately after learning [110]. Meanwhile, the endogenous activity of NE is also increased by exercise, suggesting a potential linkage between NE and exercise-enhanced cognitive function.

\subsection{Exercise and 5-HT System}

The 5-HT system is modulated by exercise, though such modulation is brain-region-dependent and is affected by the intensity and duration of exercise. Four weeks of moderate treadmill exercise decreases the levels of 5-HT without affecting the metabolism of 5-HT in the hippocampus [111]. On the contrary, seven days of high-intensity treadmill exercise significantly increases the levels of hippocampal 5-HT [112]. Furthermore, four-week moderate treadmill exercise does not change 5-HT concentration in the amygdala [111]. The levels of 5-HT and its metabolite (5-HIAA) in cortex and striatum are significantly reduced in Huntington's disease (R6/1) mice [81]. Four weeks of running-wheel exercise increases the striatal levels of 5-HIAA in the R6/1 female mice [81]. In the dorsal and median raphe nuclei, running-wheel exercise decreases the levels of 5-HT and 5-HT transporter mRNA, but increases the levels of 5-HT $\mathrm{HA}_{1 \mathrm{~A}}$ receptor mRNA [113]. The concentrations of 
5-HT in the brain stem and the hypothalamus are unaltered by wheel exercise [114]. These results indicate that the synthesis and secretion of 5-HT are affected by the intensity of exercise. The high levels of 5-HT induced by high intensity of exercise may also contribute to the central fatigue after endurance exercise. In an infraction animal model, eight days of running-wheel exercise, initiated from two days after infarction, increases the levels of 5-HT in the striatum [80]. Importantly, the levels of 5-HT positively correlate to the motor performance in rotarod test [80]. Moderate exercise has been suggested to serve as a treatment strategy for several psychiatric disorders. Although the mechanism is unclear, regulation of 5-HT receptors has been postulated as one of the potential mechanisms. Most previous studies examining the effect of exercise on 5-HT receptors only focused on 5-HT $1 \mathrm{~A}$ and $5-\mathrm{HT}_{1 \mathrm{~B}}$ receptors, leaving the other subtype of 5-HT receptors largely unknown. The effect of exercise on 5-HT receptor is also brain-region-specific. For example, chronic wheel running is known to increase the levels of $5 \mathrm{HT}_{1 \mathrm{~A}}$ receptor mRNA in the dorsal raphe nucleus [113], while the levels of such mRNA are decreased in the hippocampus [115]. Maternal separation-induced depression-like behaviors and elevation of the hippocampal $5 \mathrm{HT}_{1 \mathrm{~A}}$ receptor levels can be recovered by chronic wheel running [115]. Elevated levels of 5- $\mathrm{HT}_{1 \mathrm{~B}}$ receptor activity in the hippocampus have been reported in rats subjected to one week of moderate treadmill exercise [112]. Higher levels of 5-HT $1 \mathrm{~B}$ receptor in the hippocampus have been associated with resistance to electric stimulation-elicited learned helplessness [116]. On the contrary, mice with 5-HT $\mathrm{H}_{1 \mathrm{~B}}$ overexpression in the dorsal raphe nuclei increase anxiolytic behaviors after stress [116]. Both acute and chronic wheel running are known to reduce the level of 5- $\mathrm{HT}_{1 \mathrm{~B}}$ receptor mRNA in the dorsal raphe nuclei [113]. These findings support the proposition that exercise is an effective approach to relieve anxiety and protect the brain against uncontrollable stress $[93,117,118]$.

In addition to antidepressant and anxiolytic properties, 5-HT system has also been linked to cognitive function; a perturbation of the 5-HT system is associated with cognitive disease such as Alzheimer's disease [119-122]. 5-HT receptors are abundantly distributed throughout cognition-related brain regions, including amygdala, hippocampus and cortex [123-125]. The levels of $5-\mathrm{HT}_{1 \mathrm{~A}}$ and $5-\mathrm{HT}_{2 \mathrm{~A}}$ receptors are reduced in brains of mild cognitive impairment patients, indicating that serotonergic dysfunction may represent an early sign of Alzheimer's disease [119,122,126]. Animals that are subjected to exercise perform better in the acquisition of conditioned learning tasks than their respective controls [111,127]. The improved learning performance induced by exercise is associated with downregulation of $5-\mathrm{HT}_{1 \mathrm{~A}}$ receptor and/or upregulation of $5-\mathrm{HT}_{2 \mathrm{~A}}$ in the hippocampus [111,112,128]. An inhibition of the $\mathrm{G}_{\mathrm{i}}$ receptor (e.g., 5- $\mathrm{HT}_{1 \mathrm{~A}}$ ) activity and/or a stimulation of the $\mathrm{G}_{\mathrm{s}}$ receptor (e.g., 5- $\mathrm{HT}_{2 \mathrm{~A}}$ ) activity result in elevation of the levels of cAMP, which is critical for the process of learning and memory. Finally, 5-HT system is known to interplay with the BDNF pathway to form a positive feedback loop that plays an essential role in regulating synaptic plasticity, neurogenesis and neuronal survival in the adult brain [129].

\section{Conclusions}

An overwhelming majority of studies accredit that the monoamine systems mediate the exercise-induced enhancement of various brain functions. It is noteworthy that DA, NE and 5-HT 
receive reciprocal regulation from each other. For instance, 5-HT enhances DA release through the $5-\mathrm{HT}_{4}$ receptors in the striatum [130]. Activation of locus coeruleus induces DA secretion either directly through firing on the ventral tegmental nucleus dopaminergic neurons, or indirectly through the local glutamatergic neuron to activate neurons in the ventral tegmental nucleus $[131,132]$. Therefore, the cooperative effects of the monoamine family should also be taken into consideration, while studying the effects of exercise on brain function.

The stimulation of the monoamine system is dependent on exercise intensity. Mandatory treadmill exercise and voluntary wheel running are the two most common forms of exercise in rodent models with different exercise intensities. Treadmill exercise is more effective in enhancing the muscle aerobic capacity and in increasing the serum corticosterone level than that of wheel-running exercise [133]. The exercise-associated stress level could be an underlying modulating factor for their differential effects on brain monoamine systems. Different exercise intensities between treadmill exercise and wheel running may induce different degree of feedback in the hypothalamus-pituitary gland-adrenal gland axis. Furthermore, treadmill exercise is much more effective in activating the BDNF signaling pathway than that of wheel running in hippocampus and amygdala [134]. The effects of BDNF cannot be neglected and should be taken into consideration when studying the effects of exercise on monoamine systems.

\section{References}

1. Meeusen, R. Exercise and the brain: Insight in new therapeutic modalities. Ann. Transplant. 2005, $10,49-51$.

2. Knochel, C.; Oertel-Knochel, V.; O’Dwyer, L.; Prvulovic, D.; Alves, G.; Kollmann, B.; Hampel, H. Cognitive and behavioural effects of physical exercise in psychiatric patients. Prog. Neurobiol. 2012, 96, 46-68.

3. Tordeurs, D.; Janne, P.; Appart, A.; Zdanowicz, N.; Reynaert, C. Effectiveness of physical exercise in psychiatry: A therapeutic approach? Encephale 2011, 37, 345-352.

4. Wolff, E.; Gaudlitz, K.; von Lindenberger, B.L.; Plag, J.; Heinz, A.; Strohle, A. Exercise and physical activity in mental disorders. Eur. Arch. Psychiatry Clin. Neurosci. 2011, 261, S186-S191.

5. Carek, P.J.; Laibstain, S.E.; Carek, S.M. Exercise for the treatment of depression and anxiety. Int. J. Psychiatry Med. 2011, 41, 15-28.

6. Dinas, P.C.; Koutedakis, Y.; Flouris, A.D. Effects of exercise and physical activity on depression. Ir. J. Med. Sci. 2011, 180, 319-325.

7. Alsuwaidan, M.T.; Kucyi, A.; Law, C.W.; McIntyre, R.S. Exercise and bipolar disorder: A review of neurobiological mediators. Neuromolecular Med. 2009, 11, 328-336.

8. Archer, T. Influence of physical exercise on traumatic brain injury deficits: Scaffolding effect. Neurotox. Res. 2012, 21, 418-434.

9. Lojovich, J.M. The relationship between aerobic exercise and cognition: Is movement medicinal? J. Head Trauma Rehabil. 2010, 25, 184-192.

10. Devine, J.M.; Zafonte, R.D. Physical exercise and cognitive recovery in acquired brain injury: A review of the literature. Phys. Med. Rehabil. 2009, 1, 560-575. 
11. Achiron, A.; Kalron, A. Physical activity: Positive impact on brain plasticity. Harefuah 2008, 147, 252-255.

12. Vaynman, S.; Gomez-Pinilla, F. License to run: Exercise impacts functional plasticity in the intact and injured central nervous system by using neurotrophins. Neurorehabil. Neural Repair 2005, 19, 283-295.

13. Smith, A.D.; Zigmond, M.J. Can the brain be protected through exercise? Lessons from an animal model of parkinsonism. Exp. Neurol. 2003, 184, 31-39.

14. Hubert, M. Physical therapy for Parkinson's disease. Rev. Med. Brux. 2011, 32, 388-392.

15. Ahlskog, J.E. Does vigorous exercise have a neuroprotective effect in Parkinson disease? Neurology 2011, 77, 288-294.

16. Radak, Z.; Hart, N.; Sarga, L.; Koltai, E.; Atalay, M.; Ohno, H.; Boldogh, I. Exercise plays a preventive role against Alzheimer's disease. J. Alzheimers Dis. 2010, 20, 777-783.

17. Rolland, Y.; Abellan van Kan, G.; Vellas, B. Physical activity and Alzheimer's disease: From prevention to therapeutic perspectives. J. Am. Med. Dir. Assoc. 2008, 9, 390-405.

18. Yu, F.; Kolanowski, A.M.; Strumpf, N.E.; Eslinger, P.J. Improving cognition and function through exercise intervention in Alzheimer's disease. J. Nurs. Scholarsh. 2006, 38, 358-365.

19. Leeuwenburgh, C.; Heinecke, J.W. Oxidative stress and antioxidants in exercise. Curr. Med. Chem. 2001, 8, 829-838.

20. Parise, G.; Phillips, S.M.; Kaczor, J.J.; Tarnopolsky, M.A. Antioxidant enzyme activity is up-regulated after unilateral resistance exercise training in older adults. Free Radic. Biol. Med. 2005, 39, 289-295.

21. Cotman, C.W.; Berchtold, N.C. Exercise: A behavioral intervention to enhance brain health and plasticity. Trends Neurosci. 2002, 25, 295-301.

22. Carro, E.; Nunez, A.; Busiguina, S.; Torres-Aleman, I. Circulating insulin-like growth factor I mediates effects of exercise on the brain. J. Neurosci. 2000, 20, 2926-2933.

23. Nicklas, B.J.; Hsu, F.C.; Brinkley, T.J.; Church, T.; Goodpaster, B.H.; Kritchevsky, S.B.; Pahor, M. Exercise training and plasma C-reactive protein and interleukin-6 in elderly people. J. Am. Geriatr. Soc. 2008, 56, 2045-2052.

24. Pedersen, B.K.; Bruunsgaard, H.; Ostrowski, K.; Krabbe, K.; Hansen, H.; Krzywkowski, K.; Toft, A.; Sondergaard, S.R.; Petersen, E.W.; Ibfelt, T.; Schjerling, P. Cytokines in aging and exercise. Int. J. Sports Med. 2000, 21, S4-S9.

25. Van Praag, H. Exercise and the brain: Something to chew on. Trends Neurosci. 2009, 32, 283-290.

26. Acworth, I.; Nicholass, J.; Morgan, B.; Newsholme, E.A. Effect of sustained exercise on concentrations of plasma aromatic and branched-chain amino acids and brain amines. Biochem. Biophys. Res. Commun. 1986, 137, 149-153.

27. Newsholme, E.A.; Acworth, I.N.; Blomstrand, E. Amino Acid, Brain Neurotransmitters and a Functional Link between Muscle and Brain That Is Important in Sustained Exercise; John Libbey Eurotext Ltd.: London, UK, 1987.

28. Caperuto, E.C.; dos Santos, R.V.; Mello, M.T.; Costa Rosa, L.F. Effect of endurance training on hypothalamic serotonin concentration and performance. Clin. Exp. Pharmacol. Physiol. 2009, 36, 189-191. 
29. Blomstrand, E. A role for branched-chain amino acids in reducing central fatigue. $J$. Nutr. 2006, $136,544 \mathrm{~S}-547 \mathrm{~S}$.

30. Meeusen, R.; Watson, P.; Dvorak, J. The brain and fatigue: new opportunities for nutritional interventions? J. Sports Sci. 2006, 24, 773-782.

31. Meeusen, R.; Watson, P.; Hasegawa, H.; Roelands, B.; Piacentini, M.F. Central fatigue: The serotonin hypothesis and beyond. Sports Med. 2006, 36, 881-909.

32. Fernstrom, J.D.; Fernstrom, M.H. Exercise, serum free tryptophan, and central fatigue. J. Nutr. 2006, 136, 553S-559S.

33. Newsholme, E.A.; Blomstrand, E. Branched-chain amino acids and central fatigue. $J$. Nutr. 2006, 136, 274S-276S.

34. Yang, D.S.; Liu, X.L.; Qiao, D.C. Dynamic changes of 5-HT, DA and their metabolin in rat striatum during exhaustive exercise and recovery (in Chinese). Zhongguo Ying Yong Sheng Li Xue Za Zhi 2011, 27, 432-436.

35. Leite, L.H.; Rodrigues, A.G.; Soares, D.D.; Marubayashi, U.; Coimbra, C.C. Central fatigue induced by losartan involves brain serotonin and dopamine content. Med. Sci. Sports Exerc. 2010, 42, 1469-1476.

36. Meeusen, R.; Watson, P. Amino acids and the brain: Do they play a role in "central fatigue"? Int. J. Sport Nutr. Exerc. Metab. 2007, 17, S37-S46.

37. Jacobs, I.; Bell, D.G. Effects of acute modafinil ingestion on exercise time to exhaustion. Med. Sci. Sports Exerc. 2004, 36, 1078-1082.

38. Foley, T.E.; Fleshner, M. Neuroplasticity of dopamine circuits after exercise: Implications for central fatigue. Neuromolecular Med. 2008, 10, 67-80.

39. Guszkowska, M. Effects of exercise on anxiety, depression and mood. Psychiatr. Pol. 2004, 38, 611-620.

40. Fernandez, H.H. Updates in the medical management of Parkinson disease. Cleve. Clin. J. Med. 2012, 79, 28-35.

41. Albrecht, F.E.; Xu, J.; Moe, O.W.; Hopfer, U.; Simonds, W.F.; Orlowski, J.; Jose, P.A. Regulation of NHE3 activity by $\mathrm{G}$ protein subunits in renal brush-border membranes. Am. J. Physiol. Regul. Integr. Comp. Physiol. 2000, 278, R1064-R1073.

42. Hussain, T.; Lokhandwala, M.F. Renal dopamine DA1 receptor coupling with G(S) and G(q/11) proteins in spontaneously hypertensive rats. Am. J. Physiol. 1997, 272, F339-F346.

43. Jaber, M.; Robinson, S.W.; Missale, C.; Caron, M.G. Dopamine receptors and brain function. Neuropharmacology 1996, 35, 1503-1519.

44. Sidhu, A.; Niznik, H.B. Coupling of dopamine receptor subtypes to multiple and diverse G proteins. Int. J. Dev. Neurosci. 2000, 18, 669-677.

45. Calabresi, P.; Picconi, B.; Tozzi, A.; di Filippo, M. Dopamine-mediated regulation of corticostriatal synaptic plasticity. Trends Neurosci. 2007, 30, 211-219.

46. Calabresi, P.; Pisani, A.; Centonze, D.; Bernardi, G. Role of dopamine receptors in the short- and long-term regulation of corticostriatal transmission. Nihon Shinkei Seishin Yakurigaku Zasshi 1997, 17, 101-104.

47. Bagetta, V.; Ghiglieri, V.; Sgobio, C.; Calabresi, P.; Picconi, B. Synaptic dysfunction in Parkinson's disease. Biochem. Soc. Trans. 2010, 38, 493-497. 
48. Lovinger, D.M. Neurotransmitter roles in synaptic modulation, plasticity and learning in the dorsal striatum. Neuropharmacology 2010, 58, 951-961.

49. Wilson, C.J. Striatal D2 receptors and LTD: Yes, but not where you thought they were. Neuron 2006, 50, 347-348.

50. Chen, Z.; Ito, K.; Fujii, S.; Miura, M.; Furuse, H.; Sasaki, H.; Kaneko, K.; Kato, H.; Miyakawa, H. Roles of dopamine receptors in long-term depression: Enhancement via D1 receptors and inhibition via D2 receptors. Receptors Channels 1996, 4, 1-8.

51. Bouret, S.; Sara, S.J. Network reset: A simplified overarching theory of locus coeruleus noradrenaline function. Trends Neurosci. 2005, 28, 574-582.

52. Berridge, C.W.; Waterhouse, B.D. The locus coeruleus-noradrenergic system: Modulation of behavioral state and state-dependent cognitive processes. Brain Res. Brain Res. Rev. 2003, 42, 33-84.

53. Piascik, M.T.; Perez, D.M. Alpha1-adrenergic receptors: New insights and directions. J. Pharmacol. Exp. Ther. 2001, 298, 403-410.

54. Hertz, L.; Peng, L.; Dienel, G.A. Energy metabolism in astrocytes: High rate of oxidative metabolism and spatiotemporal dependence on glycolysis/glycogenolysis. J. Cereb. Blood Flow Metab. 2007, 27, 219-249.

55. Ma, Y.C.; Huang, X.Y. Novel signaling pathway through the beta-adrenergic receptor. Trends Cardiovasc. Med. 2002, 12, 46-49.

56. Graeff, F.G.; Guimaraes, F.S.; de Andrade, T.G.; Deakin, J.F. Role of 5-HT in stress, anxiety, and depression. Pharmacol. Biochem. Behav. 1996, 54, 129-141.

57. Owens, M.J.; Nemeroff, C.B. Role of serotonin in the pathophysiology of depression: Focus on the serotonin transporter. Clin. Chem. 1994, 40, 288-295.

58. Asarnow, J.R.; Emslie, G.; Clarke, G.; Wagner, K.D.; Spirito, A.; Vitiello, B.; Iyengar, S.; Shamseddeen, W.; Ritz, L.; McCracken, J.; et al. Treatment of selective serotonin reuptake inhibitor-resistant depression in adolescents: Predictors and moderators of treatment response. J. Am. Acad. Child. Adolesc. Psychiatry 2009, 48, 330-339.

59. Hoyer, D.; Hannon, J.P.; Martin, G.R. Molecular, pharmacological and functional diversity of 5-HT receptors. Pharmacol. Biochem. Behav. 2002, 71, 533-554.

60. Lopez-Figueroa, A.L.; Norton, C.S.; Lopez-Figueroa, M.O.; Armellini-Dodel, D.; Burke, S.; Akil, H.; Lopez, J.F.; Watson, S.J. Serotonin 5-HT1A, 5-HT1B, and 5-HT2A receptor mRNA expression in subjects with major depression, bipolar disorder, and schizophrenia. Biol. Psychiatry 2004, 55, 225-233.

61. De Vry, J. 5-HT1A receptor agonists: Recent developments and controversial issues. Psychopharmacology (Berl.) 1995, 121, 1-26.

62. Murrough, J.W.; Neumeister, A. The serotonin 1B receptor: A new target for depression therapeutics? Biol. Psychiatry 2011, 69, 714-715.

63. Watson, J.M.; Dawson, L.A. Characterization of the potent 5-HT(1A/B) receptor antagonist and serotonin reuptake inhibitor SB-649915: Preclinical evidence for hastened onset of antidepressant/anxiolytic efficacy. CNS Drug Rev. 2007, 13, 206-223.

64. Moret, C.; Briley, M. The possible role of 5-HT(1B/D) receptors in psychiatric disorders and their potential as a target for therapy. Eur. J. Pharmacol. 2000, 404, 1-12. 
65. Ebdrup, B.H.; Rasmussen, H.; Arnt, J.; Glenthoj, B. Serotonin 2A receptor antagonists for treatment of schizophrenia. Expert Opin. Investig. Drugs 2011, 20, 1211-1223.

66. Tiwari, A.K.; Souza, R.P.; Muller, D.J. Pharmacogenetics of anxiolytic drugs. J. Neural Transm. 2009, 116, 667-677.

67. Berg, K.A.; Harvey, J.A.; Spampinato, U.; Clarke, W.P. Physiological and therapeutic relevance of constitutive activity of 5-HT 2A and 5-HT 2C receptors for the treatment of depression. Prog. Brain Res. 2008, 172, 287-305.

68. Adell, A.; Castro, E.; Celada, P.; Bortolozzi, A.; Pazos, A.; Artigas, F. Strategies for producing faster acting antidepressants. Drug Discov. Today 2005, 10, 578-585.

69. Celada, P.; Puig, M.; Amargos-Bosch, M.; Adell, A.; Artigas, F. The therapeutic role of 5-HT1A and 5-HT2A receptors in depression. J. Psychiatry Neurosci. 2004, 29, 252-265.

70. De Angelis, L. 5-HT2A antagonists in psychiatric disorders. Curr. Opin. Investig. Drugs 2002, 3, 106-112.

71. Pauwels, P.J. 5-HT 1B/D receptor antagonists. Gen. Pharmacol. 1997, 29, 293-303.

72. Hoyer, D.; Clarke, D.E.; Fozard, J.R.; Hartig, P.R.; Martin, G.R.; Mylecharane, E.J.; Saxena, P.R.; Humphrey, P.P. International Union of Pharmacology classification of receptors for 5-hydroxytryptamine (Serotonin). Pharmacol. Rev. 1994, 46, 157-203.

73. Deslandes, A.; Moraes, H.; Ferreira, C.; Veiga, H.; Silveira, H.; Mouta, R.; Pompeu, F.A.; Coutinho, E.S.; Laks, J. Exercise and mental health: Many reasons to move. Neuropsychobiology 2009, 59, 191-198.

74. Wipfli, B.; Landers, D.; Nagoshi, C.; Ringenbach, S. An examination of serotonin and psychological variables in the relationship between exercise and mental health. Scand. J. Med. Sci. Sports 2011, 21, 474-481.

75. Yau, S.Y.; Lau, B.W.; So, K.F. Adult hippocampal neurogenesis: A possible way how physical exercise counteracts stress. Cell Transplant. 2011, 20, 99-111.

76. De Castro, J.M.; Duncan, G. Operantly conditioned running: Effects on brain catecholamine concentrations and receptor densities in the rat. Pharmacol. Biochem. Behav. 1985, 23, 495-500.

77. Sutoo, D.; Akiyama, K. Regulation of brain function by exercise. Neurobiol. Dis. 2003, 13, 1-14.

78. MacRae, P.G.; Spirduso, W.W.; Walters, T.J.; Farrar, R.P.; Wilcox, R.E. Endurance training effects on striatal D2 dopamine receptor binding and striatal dopamine metabolites in presenescent older rats. Psychopharmacology (Berl.) 1987, 92, 236-240.

79. MacRae, P.G.; Spirduso, W.W.; Cartee, G.D.; Farrar, R.P.; Wilcox, R.E. Endurance training effects on striatal D2 dopamine receptor binding and striatal dopamine metabolite levels. Neurosci. Lett. 1987, 79, 138-144.

80. Mizutani, K.; Sonoda, S.; Karasawa, N.; Yamada, K.; Shimpo, K.; Chihara, T.; Takeuchi, T.; Hasegawa, Y.; Kubo, K.Y. Effects of exercise after focal cerebral cortex infarction on basal ganglion. Neurol. Sci. 2012, doi:10.1007/s10072-012-1137-3.

81. Renoir, T.; Chevarin, C.; Lanfumey, L.; Hannan, A.J. Effect of enhanced voluntary physical exercise on brain levels of monoamines in Huntington disease mice. PLoS Curr. 2011, 3, doi:10.1371/currents.RRN1281. 
82. Petzinger, G.M.; Walsh, J.P.; Akopian, G.; Hogg, E.; Abernathy, A.; Arevalo, P.; Turnquist, P.; Vuckovic, M.; Fisher, B.E.; Togasaki, D.M.; Jakowec, M.W. Effects of treadmill exercise on dopaminergic transmission in the 1-methyl-4-phenyl-1,2,3,6-tetrahydropyridine-lesioned mouse model of basal ganglia injury. J. Neurosci. 2007, 27, 5291-5300.

83. Fisher, B.E.; Petzinger, G.M.; Nixon, K.; Hogg, E.; Bremmer, S.; Meshul, C.K.; Jakowec, M.W. Exercise-induced behavioral recovery and neuroplasticity in the 1-methyl-4-phenyl-1,2,3,6-tetrahydropyridine-lesioned mouse basal ganglia. J. Neurosci. Res. 2004, 77, 378-390.

84. Vuckovic, M.G.; Li, Q.; Fisher, B.; Nacca, A.; Leahy, R.M.; Walsh, J.P.; Mukherjee, J.; Williams, C.; Jakowec, M.W.; Petzinger, G.M. Exercise elevates dopamine D2 receptor in a mouse model of Parkinson's disease: In vivo imaging with [(1)(8)F]fallypride. Mov. Disord. 2010, 25, 2777-2784.

85. Yoon, M.C.; Shin, M.S.; Kim, T.S.; Kim, B.K.; Ko, I.G.; Sung, Y.H.; Kim, S.E.; Lee, H.H.; Kim, Y.P.; Kim, C.J. Treadmill exercise suppresses nigrostriatal dopaminergic neuronal loss in 6-hydroxydopamine-induced Parkinson's rats. Neurosci. Lett. 2007, 423, 12-17.

86. Tajiri, N.; Yasuhara, T.; Shingo, T.; Kondo, A.; Yuan, W.; Kadota, T.; Wang, F.; Baba, T.; Tayra, J.T.; Morimoto, T.; et al. Exercise exerts neuroprotective effects on Parkinson's disease model of rats. Brain Res. 2010, 1310, 200-207.

87. Mabandla, M.; Kellaway, L.; St Clair Gibson, A.; Russell, V.A. Voluntary running provides neuroprotection in rats after 6-hydroxydopamine injection into the medial forebrain bundle. Metab. Brain Dis. 2004, 19, 43-50.

88. Gerecke, K.M.; Jiao, Y.; Pani, A.; Pagala, V.; Smeyne, R.J. Exercise protects against MPTP-induced neurotoxicity in mice. Brain Res. 2010, 1341, 72-83.

89. Wu, S.Y.; Wang, T.F.; Yu, L.; Jen, C.J.; Chuang, J.I.; Wu, F.S.; Wu, C.W.; Kuo, Y.M. Running exercise protects the substantia nigra dopaminergic neurons against inflammation-induced degeneration via the activation of BDNF signaling pathway. Brain Behav. Immun. 2011, 25, 135-146.

90. Tanaka, K.; Quadros, A.C., Jr.; Santos, R.F.; Stella, F.; Gobbi, L.T.; Gobbi, S. Benefits of physical exercise on executive functions in older people with Parkinson's disease. Brain Cogn. 2009, 69, $435-441$.

91. Xu, Q.; Park, Y.; Huang, X.; Hollenbeck, A.; Blair, A.; Schatzkin, A.; Chen, H. Physical activities and future risk of Parkinson disease. Neurology 2010, 75, 341-348.

92. Greenwood, B.N.; Kennedy, S.; Smith, T.P.; Campeau, S.; Day, H.E.; Fleshner, M. Voluntary freewheel running selectively modulates catecholamine content in peripheral tissue and c-Fos expression in the central sympathetic circuit following exposure to uncontrollable stress in rats. Neuroscience 2003, 120, 269-281.

93. Greenwood, B.N.; Fleshner, M. Exercise, learned helplessness, and the stress-resistant brain. Neuromolecular Med. 2008, 10, 81-98.

94. Sciolino, N.R.; Holmes, P.V. Exercise offers anxiolytic potential: A role for stress and brain noradrenergic-galaninergic mechanisms. Neurosci. Biobehav. Rev. 2012, 36, 1965-1984. 
95. Pieribone, V.A.; Xu, Z.Q.; Zhang, X.; Grillner, S.; Bartfai, T.; Hokfelt, T. Galanin induces a hyperpolarization of norepinephrine-containing locus coeruleus neurons in the brainstem slice. Neuroscience 1995, 64, 861-874.

96. Seutin, V.; Verbanck, P.; Massotte, L.; Dresse, A. Galanin decreases the activity of locus coeruleus neurons in vitro. Eur. J. Pharmacol. 1989, 164, 373-376.

97. O’Neal, H.A.; van Hoomissen, J.D.; Holmes, P.V.; Dishman, R.K. Prepro-galanin messenger RNA levels are increased in rat locus coeruleus after treadmill exercise training. Neurosci. Lett. 2001, 299, 69-72.

98. Murray, P.S.; Groves, J.L.; Pettett, B.J.; Britton, S.L.; Koch, L.G.; Dishman, R.K.; Holmes, P.V. Locus coeruleus galanin expression is enhanced after exercise in rats selectively bred for high capacity for aerobic activity. Peptides 2010, 31, 2264-2268.

99. Reiss, J.I.; Dishman, R.K.; Boyd, H.E.; Robinson, J.K.; Holmes, P.V. Chronic activity wheel running reduces the severity of kainic acid-induced seizures in the rat: Possible role of galanin. Brain Res. 2009, 1266, 54-63.

100. Van Hoomissen, J.D.; Holmes, P.V.; Zellner, A.S.; Poudevigne, A.; Dishman, R.K. Effects of beta-adrenoreceptor blockade during chronic exercise on contextual fear conditioning and mRNA for galanin and brain-derived neurotrophic factor. Behav. Neurosci. 2004, 118, 1378-1390.

101. Legakis, I.N.; Mantzouridis, T.; Saramantis, A.; Phenekos, C.; Tzioras, C.; Mountokalakis, T. Human galanin secretion is increased upon normal exercise test in middle-age individuals. Endocr. Res. 2000, 26, 357-364.

102. Murchison, C.F.; Zhang, X.Y.; Zhang, W.P.; Ouyang, M.; Lee, A.; Thomas, S.A. A distinct role for norepinephrine in memory retrieval. Cell 2004, 117, 131-143.

103. Tully, K.; Bolshakov, V.Y. Emotional enhancement of memory: How norepinephrine enables synaptic plasticity. Mol. Brain 2010, 3, 15.

104. Groch, S.; Wilhelm, I.; Diekelmann, S.; Sayk, F.; Gais, S.; Born, J. Contribution of norepinephrine to emotional memory consolidation during sleep. Psychoneuroendocrinology 2011, 36, $1342-1350$.

105. Szot, P. Common factors among Alzheimer's disease, Parkinson's disease, and epilepsy: Possible role of the noradrenergic nervous system. Epilepsia 2012, 53, 61-66.

106. Vazey, E.M.; Aston-Jones, G. The emerging role of norepinephrine in cognitive dysfunctions of Parkinson's disease. Front. Behav. Neurosci. 2012, 6, 48.

107. Dunn, A.L.; Reigle, T.G.; Youngstedt, S.D.; Armstrong, R.B.; Dishman, R.K. Brain norepinephrine and metabolites after treadmill training and wheel running in rats. Med.Sci. Sports Exerc. 1996, 28, 204-209.

108. Sarbadhikari, S.N.; Saha, A.K. Moderate exercise and chronic stress produce counteractive effects on different areas of the brain by acting through various neurotransmitter receptor subtypes: A hypothesis. Theor. Biol. Med. Model. 2006, 3, 33.

109. Ebrahimi, S.; Rashidy-Pour, A.; Vafaei, A.A.; Akhavan, M.M. Central beta-adrenergic receptors play an important role in the enhancing effect of voluntary exercise on learning and memory in rat. Behav. Brain Res. 2010, 208, 189-193. 
110. Segal, S.K.; Cotman, C.W.; Cahill, L.F. Exercise-induced noradrenergic activation enhances memory consolidation in both normal aging and patients with amnestic mild cognitive impairment. J. Alzheimers Dis. 2012, 32, 1011-1018.

111. Chen, H.I.; Lin, L.C.; Yu, L.; Liu, Y.F.; Kuo, Y.M.; Huang, A.M.; Chuang, J.I.; Wu, F.S.; Liao, P.C.; Jen, C.J. Treadmill exercise enhances passive avoidance learning in rats: The role of down-regulated serotonin system in the limbic system. Neurobiol. Learn. Mem. 2008, 89, 489-496.

112. Chennaoui, M.; Grimaldi, B.; Fillion, M.P.; Bonnin, A.; Drogou, C.; Fillion, G.; Guezennec, C.Y. Effects of physical training on functional activity of 5-HT1B receptors in rat central nervous system: Role of 5-HT-moduline. Naunyn Schmiedebergs Arch. Pharmacol. 2000, 361, 600-604.

113. Greenwood, B.N.; Foley, T.E.; Day, H.E.; Burhans, D.; Brooks, L.; Campeau, S.; Fleshner, M. Wheel running alters serotonin (5-HT) transporter, 5-HT1A, 5-HT1B, and alpha 1b-adrenergic receptor mRNA in the rat raphe nuclei. Biol. Psychiatry 2005, 57, 559-568.

114. Samorajski, T.; Rolsten, C.; Przykorska, A.; Davis, C.M. Voluntary wheel running exercise and monoamine levels in brain, heart and adrenal glands of aging mice. Exp. Gerontol. 1987, 22, 421-431.

115. Maniam, J.; Morris, M.J. Voluntary exercise and palatable high-fat diet both improve behavioural profile and stress responses in male rats exposed to early life stress: Role of hippocampus. Psychoneuroendocrinology 2010, 35, 1553-1564.

116. Neumaier, J.F.; Edwards, E.; Plotsky, P.M. 5-HT(1B) mrna regulation in two animal models of altered stress reactivity. Biol. Psychiatry 2002, 51, 902-908.

117. Greenwood, B.N.; Strong, P.V.; Dorey, A.A.; Fleshner, M. Therapeutic effects of exercise: Wheel running reverses stress-induced interference with shuttle box escape. Behav. Neurosci. 2007, 121, 992-1000.

118. Greenwood, B.N.; Foley, T.E.; Day, H.E.; Campisi, J.; Hammack, S.H.; Campeau, S.; Maier, S.F.; Fleshner, M. Freewheel running prevents learned helplessness/behavioral depression: Role of dorsal raphe serotonergic neurons. J. Neurosci. 2003, 23, 2889-2898.

119. Meltzer, C.C.; Smith, G.; DeKosky, S.T.; Pollock, B.G.; Mathis, C.A.; Moore, R.Y.; Kupfer, D.J.; Reynolds, C.F., III. Serotonin in aging, late-life depression, and Alzheimer's disease: The emerging role of functional imaging. Neuropsychopharmacology 1998, 18, 407-430.

120. Reynolds, G.P.; Mason, S.L.; Meldrum, A.; de Keczer, S.; Parnes, H.; Eglen, R.M.; Wong, E.H. 5-Hydroxytryptamine (5-HT)4 receptors in post mortem human brain tissue: Distribution, pharmacology and effects of neurodegenerative diseases. Br. J. Pharmacol. 1995, 114, 993-998.

121. Kan, R.; Wang, B.; Zhang, C.; Yang, Z.; Ji, S.; Lu, Z.; Zheng, C.; Jin, F.; Wang, L. Association of the HTR6 polymorphism C267T with late-onset Alzheimer's disease in Chinese. Neurosci. Lett. 2004, 372, 27-29.

122. Francis, P.T.; Pangalos, M.N.; Bowen, D.M. Animal and drug modelling for Alzheimer synaptic pathology. Prog. Neurobiol. 1992, 39, 517-545.

123. Meneses, A. 5-HT system and cognition. Neurosci. Biobehav. Rev. 1999, 23, 1111-1125.

124. Meneses, A.; Perez-Garcia, G. 5-HT(1A) receptors and memory. Neurosci. Biobehav. Rev. 2007, $31,705-727$. 
125. King, M.V.; Marsden, C.A.; Fone, K.C. A role for the 5-HT(1A), 5-HT4 and 5-HT6 receptors in learning and memory. Trends Pharmacol. Sci. 2008, 29, 482-492.

126. Hasselbalch, S.G.; Madsen, K.; Svarer, C.; Pinborg, L.H.; Holm, S.; Paulson, O.B.; Waldemar, G.; Knudsen, G.M. Reduced 5-HT2A receptor binding in patients with mild cognitive impairment. Neurobiol. Aging 2008, 29, 1830-1838.

127. Harvey, J.A. Role of the serotonin 5-HT(2A) receptor in learning. Learn. Mem. 2003, 10, 355-362.

128. Renoir, T.; Pang, T.Y.; Zajac, M.S.; Chan, G.; Du, X.; Leang, L.; Chevarin, C.; Lanfumey, L.; Hannan, A.J. Treatment of depressive-like behaviour in Huntington's disease mice by chronic sertraline and exercise. Br. J. Pharmacol. 2012, 165, 1375-1389.

129. Mattson, M.P.; Maudsley, S.; Martin, B. BDNF and 5-HT: A dynamic duo in age-related neuronal plasticity and neurodegenerative disorders. Trends Neurosci. 2004, 27, 589-594.

130. De Deurwaerdere, P.; L'Hirondel, M.; Bonhomme, N.; Lucas, G.; Cheramy, A.; Spampinato, U. Serotonin stimulation of 5-HT4 receptors indirectly enhances in vivo dopamine release in the rat striatum. J. Neurochem. 1997, 68, 195-203.

131. Sara, S.J. The locus coeruleus and noradrenergic modulation of cognition. Nat. Rev. Neurosci. 2009, 10, 211-223.

132. Smith, C.C.; Greene, R.W. CNS dopamine transmission mediated by noradrenergic innervation. J. Neurosci. 2012, 32, 6072-6080.

133. Liu, Y.F.; Chen, H.I.; Wu, C.L.; Kuo, Y.M.; Yu, L.; Huang, A.M.; Wu, F.S.; Chuang, J.I.; Jen, C.J. Differential effects of treadmill running and wheel running on spatial or aversive learning and memory: roles of amygdalar brain-derived neurotrophic factor and synaptotagmin I. J. Physiol. 2009, 587, 3221-3231.

134. Lin, T.W.; Chen, S.J.; Huang, T.Y.; Chang, C.Y.; Chuang, J.I.; Wu, F.S.; Kuo, Y.M.; Jen, C.J. Different types of exercise induce differential effects on neuronal adaptations and memory performance. Neurobiol. Learn. Mem. 2012, 97, 140-147.

(C) 2013 by the authors; licensee MDPI, Basel, Switzerland. This article is an open access article distributed under the terms and conditions of the Creative Commons Attribution license (http://creativecommons.org/licenses/by/3.0/). 